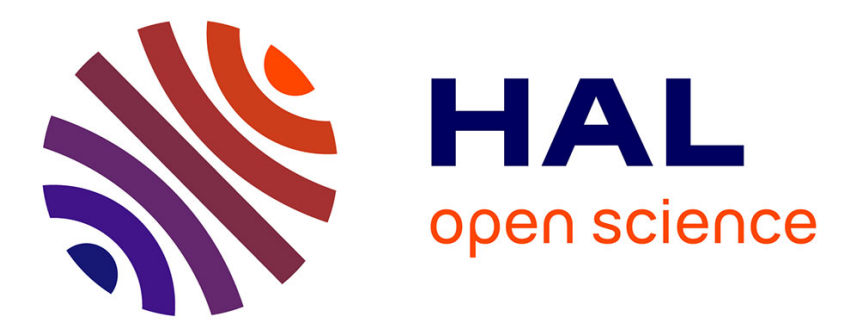

\title{
Dietary cadmium intake by the Belgian adult population
}

\author{
Valérie Vromman, Nadia Waegeneers, Christa Cornelis, Isabel de Boosere, \\ Mirja van Holderbeke, Christine Vinkx, Erik Smolders, André Huyghebaert, \\ Luc Pussemier
}

\section{- To cite this version:}

Valérie Vromman, Nadia Waegeneers, Christa Cornelis, Isabel de Boosere, Mirja van Holderbeke, et al. Dietary cadmium intake by the Belgian adult population. Food Additives and Contaminants, 2010, 27 (12), pp.1665-1673. 10.1080/19440049.2010.525752 . hal-00643846

\section{HAL Id: hal-00643846 \\ https://hal.science/hal-00643846}

Submitted on 23 Nov 2011

HAL is a multi-disciplinary open access archive for the deposit and dissemination of scientific research documents, whether they are published or not. The documents may come from teaching and research institutions in France or abroad, or from public or private research centers.
L'archive ouverte pluridisciplinaire HAL, est destinée au dépôt et à la diffusion de documents scientifiques de niveau recherche, publiés ou non, émanant des établissements d'enseignement et de recherche français ou étrangers, des laboratoires publics ou privés. 


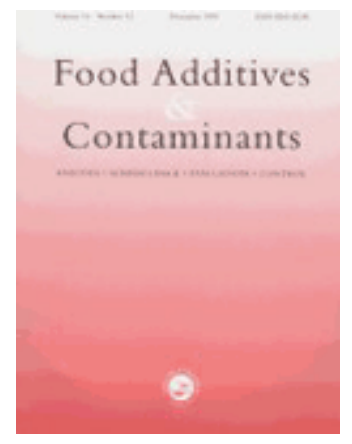

\section{Dietary cadmium intake by the Belgian adult population}

\begin{tabular}{|c|c|}
\hline Journal: & Food Additives and Contaminants \\
\hline Manuscript ID: & TFAC-2010-150.R1 \\
\hline Manuscript Type: & Original Research Paper \\
\hline $\begin{array}{r}\text { Date Submitted by the } \\
\text { Author: }\end{array}$ & 14-Sep-2010 \\
\hline Complete List of Authors: & $\begin{array}{l}\text { Vromman, Valérie; FASFC, DG Control Policy } \\
\text { WAEGENEERS, Nadia; Veterinary and Agrochemical Research } \\
\text { Centre } \\
\text { CORNELIS, Christa; VITO, Unit Environmental Risk and Health } \\
\text { DE BOOSERE, Isabel; Federal public service, Health, food chain } \\
\text { safety and environment } \\
\text { VAN HOLDERBEKE, Mirja; VITO, Unit Environmental Risk and Health } \\
\text { Vinkx, Christine; Federal public service, Health, food chain safety } \\
\text { and environment } \\
\text { SMOLDERS, Erik; University of Leuven, Division Soil and Water } \\
\text { Management } \\
\text { Huyghebaert, André; Ghent University, Department of Food Safety } \\
\text { and Quality } \\
\text { Pussemier, Luc; Veterinary and Agrochemical Research Centre }\end{array}$ \\
\hline Methods/Techniques: & AAS, ICP/MS \\
\hline Additives/Contaminants: & Heavy metals - cadmium \\
\hline Food Types: & Potatoes, Bread, Cereals, Vegetables \\
\hline
\end{tabular}

\section{SCHOLARONE ${ }^{m}$ \\ Manuscripts}




\title{
Dietary cadmium intake by the Belgian adult population
}

\author{
V. VROMMAN ${ }^{1 *}$, N. WAEGENEERS ${ }^{2}$, C. CORNELIS $^{3}$, I. DE BOOSERE ${ }^{4}$, M. VAN

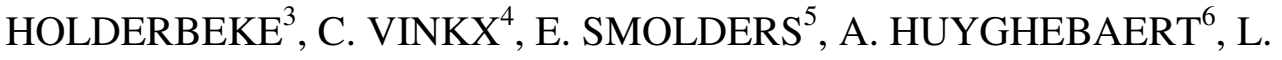 \\ PUSSEMIER $^{2}$
}

1 Federal Agency for the Safety of the Food Chain, Administration of Control Policy, Secretariat of the Scientific Committee, Boulevard du Jardin Botanique 55, B-1000 Brussels, Belgium

2

Veterinary and Agrochemical Research Centre (CODA-CERVA), Leuvensesteenweg 17, B-3080 Tervuren, Belgium

VITO, Unit Environmental Risk and Health, Boeretang 200, B-2400 Mol, Belgium

$4 \quad$ Federal public service, Health, food chain safety and environment, Place Victor Horta 40 Box 10, B-1060 Brussels, Belgium

5 Division Soil and Water Management, University of Leuven, Kasteelpark Arenberg 20, B-3001 Leuven, Belgium

6 Department of Food Safety and Quality, Ghent University, Coupure Links 653, B-9000 Ghent, Belgium.

Running head: Dietary cadmium intake by the Belgian adult population

*Vromman Valérie. Email : valerie.vromman@afsca.be

http://mc.manuscriptcentral.com/tfac Email: fac@tandf.co.uk 


\begin{abstract}
The aim of this study was to estimate the dietary cadmium (Cd) intake of the Belgian adult population, to compare this dietary $\mathrm{Cd}$ exposure to the tolerable weekly intake (TWI) recently established by the European Food Safety Authority (EFSA) and to determine the major food groups that contribute to dietary $\mathrm{Cd}$ exposure in Belgium. Food consumption data were derived from the 2004 Belgian food consumption survey (two 24h recalls, 3,083 participants). Cadmium concentrations in food items $(n=4,000)$ were gathered from the control program of the Belgian Federal Agency for the Safety of the Food Chain for the period 2006-2008. Dietary intake per individual was calculated from consumption data and median $\mathrm{Cd}$ concentrations. The population mean, median and $95^{\text {th }}$ percentile of the dietary intake values were $0.98,0.85$ and $2.02 \mu \mathrm{g} \mathrm{kg}^{-1}$ body weight per week respectively. Two percent of the Belgian adult population has a dietary Cd intake above the recent TWI of $2.5 \mathrm{\mu g} \mathrm{kg}^{-1}$ body weight established by EFSA. Cereal products and potatoes contribute for more than $60 \%$ to $\mathrm{Cd}$ intake.
\end{abstract}

Keywords : cadmium, dietary intake, risk assessment, cereal products.

\title{
Introduction
}

Cadmium is a non essential trace element. It is mainly an environmental contaminant, which on the one hand, is naturally present in the environment and on the other hand, may originate from industrial and agricultural sources.

Food, including drinks, is the main source of Cd exposure for the non-smoking and nonoccupationally exposed part of the population (WHO 1992). Fouassin and Fondu (1981) evaluated the average $\mathrm{Cd}$ concentration in food from the daily diet and estimated $\mathrm{Cd}$ dietary intake of the Belgian population at $48 \mu \mathrm{g}$ per day. More than 2,500 food samples in big and small market were taken and analyzed by atomic absorption spectrometry or 
by electrothermal atomic absorption spectrometry. In 1993, Van Assche and Ciarletta compared the data from Fouassin and Fondu (1981) with analysis result from 1989. They observed a decline of $\mathrm{Cd}$ concentration in food which may presumed be due to the decrease in direct atmospheric deposition of Cd onto crops and soils.

Cadmium might constitute a serious health hazard for large groups of the population because it can bioaccumulate (Marzec and Schlegel-Zawadzka 2004). The half-life of $\mathrm{Cd}$ in the human body is 10 to 30 years (Nawrot et al. 2006). The most severe form of foodborne chronic Cd intoxication is the Itai Itai disease (Kobayashi et al. 2009), which combines bone disorders and renal effects and is characterized by extreme pain. The disease was mainly diagnosed in a limited area in Japan that had been polluted. Cadmium concentrations found in locally grown rice were ten times higher than in other areas (Moritsugi and Kobayashi 1964 cited in EC 2007). The most critical organ, i.e. the organ that exhibits the first adverse effects in long-term low-level $\mathrm{Cd}$ exposure, is the kidney. The critical effect is renal tubular dysfunction, which is often manifested as the presence of low molecular weight proteins (e.g. $\beta$-2-microglobulin) in urine (FAO/WHO 2000). In the general population, i.e. at low (dietary) Cd exposure, the urinary excretion of $\mathrm{Cd}$ reflects the amount stored in the kidney, as long as the amount of absorbed $\mathrm{Cd}$ has not yet saturated all Cd-binding sites, and increases progressively with age (Lauwerys et al. 1994). Once the binding sites become saturated (i.e. after excessive exposure), further absorbed $\mathrm{Cd}$ is rapidly excreted in urine. When $\mathrm{Cd}$-induced renal tubular damage develops, a considerable increase in the urinary excretion of $\mathrm{Cd}$ occurs because of its loss from the renal depot (Lauwerys et al. 1994). Several markers of renal tubular function, such as $\beta$-2-microglobulin, are significantly and positively associated with urinary Cd (Lauwerys et al. 1991).

A provisional tolerable weekly intake (PTWI) for Cd of $7 \mu \mathrm{g} \mathrm{kg}^{-1}$ body weight was established by the Joint FAO/WHO Expert Committee on Food Additives (JECFA; FAO/WHO 2004) and endorsed in 1995 by the Scientific Committee for Food of the European Commission (SCF 1995). The PTWI was based on the prevalence of renal tubular dysfunction, a biomarker of toxicity, and set at such a level that the Cd concentration in the renal cortex would not exceed $50 \mu \mathrm{g} \mathrm{g}^{-1}$ after 50 years of exposure. 
The health risk related to $\mathrm{Cd}$ exposure has recently been re-evaluated by the Scientific Panel on Contaminants in the Food Chain (CONTAM) of the European Food Safety Authority (EFSA), which established a tolerable weekly intake (TWI) of $2.5 \mu \mathrm{g} \mathrm{kg}^{-1}$ body weight (EFSA 2009). The establishment of the TWI was based on a meta-analysis to evaluate the dose-response relationship between urinary $\mathrm{Cd}$ and urinary $\beta$-2-

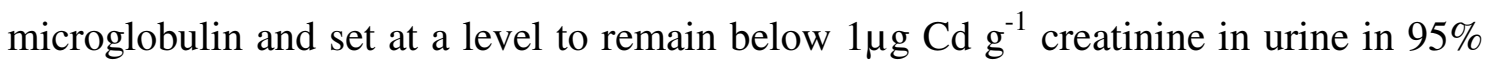
of the population by age 50 (EFSA 2009).

The objective of this study was to estimate the dietary $\mathrm{Cd}$ intake of the general adult population in Belgium, to compare this dietary Cd exposure to the new TWI established by EFSA and to determine which food groups are the major contributors to the dietary $\mathrm{Cd}$ exposure. Dietary $\mathrm{Cd}$ intake was also calculated for individuals who follow the nutritional recommendations for the consumption of vegetables or fish and compared to the TWI established by EFSA.

\section{Materials and methods \\ Cadmium data}

Food items were sampled in the framework of the control program of the Belgian Federal Agency for the Safety of the Food Chain (FASFC) in the period 2006-2008. The goal of this program is to control the conformity with regulations and to guarantee food safety (Maudoux et al. 2006). The samples were analyzed in different accredited laboratories and by using different analytical methods (inter alia atomic absorption spectrometry, inductively coupled plasma-mass spectrometry). The methods used are among others subject to interlaboratory trials to check the quality of the results. Only the edible portion of the samples were analyzed. The limit of detection (LOD) or quantification (LOQ) for the analyses varied with the food matrix, the analytical technique used and per laboratory. The sensitivity of an analytical method is, for cost and time reasons, often set by the laboratory to fulfill legislative requirements and not fine-tuned to optimal sensitivity. This is perfectly satisfactory for routine monitoring purposes, but does cause slight problems when results are used to calculate human exposure (EFSA 2009). The calculation of the descriptive statistics for the 
concentrations of $\mathrm{Cd}$ was performed by also taking into account the samples with results below the LOD. Such samples do not necessarily indicate that $\mathrm{Cd}$ is not present in the sample, but only that the analytical method could not detect the possible amount of Cd present. These samples were assigned a value of half the limit of detection (middle bound principle). In some cases, the samples were reported as a concentration value below the limit of quantification (LOQ). In these cases the numeric concentration was estimated as half of the limit of quantification.

The results of the middle bound scenario were compared with a lower bound scenario in which samples with Cd levels below the LOD or LOQ were set to zero, and an upper bound (worst-case) scenario in which samples with Cd levels below the LOD or LOQ were set to the LOD or LOQ respectively. According to WHO (1995), two estimates using zero and LOD for all results less than LOD must be done if the proportion of samples below the LOD is between 60 and $80 \%$.

\section{Food consumption data}

A Belgian national food consumption survey was performed in 2004 by the Belgian Institute for Public Health. Aims, design and methods of this survey are described elsewhere (De Vriese et al. 2005). This survey describes the food consumption schema of 3,083 participants over 15 years of age. Information on food intake was collected using two non-consecutive $24 \mathrm{~h}$ recalls in combination with a self-administered food frequency questionnaire. The selection of interviewed people and the moment of the interview were chosen in order to obtain a representative consumption profile of the Belgian population spread over one year. The dietary Cd exposure of the Belgian adult population ( $>15$ years of age) was estimated based on the mean consumption of the food items over the two non-consecutive days.

\section{Estimation of cadmium intake}

Cadmium was analyzed in 55 categories (food items) of foods. Liver of horse, game and bovine like kidneys of horse, game and bovine were grouped for the determination of the Cd intake. 
The $\mathrm{Cd}$ intake was calculated by a deterministic approach multiplying for each food item the median $\mathrm{Cd}$ concentration by its mean consumption.

The use of the median Cd concentration in food was preferred over the use of the mean concentration because the latter is more sensitive to extreme values. The obtained results were summed up for all food items to estimate an overall exposure. The dietary Cd intake was compared to the TWI of $2.5 \mu \mathrm{g} \mathrm{kg}^{-1}$ body weight set by EFSA (2009) as:

$$
\% \mathrm{TWI}=\frac{\text { daily dietary Cd intake }\left(\mu \mathrm{g} \mathrm{day}^{-1}\right) \cdot 7(\text { day })}{2.5\left(\mu \mathrm{g} \mathrm{kg}^{-1} \text { body weight }\right) \cdot \text { body weight }(\mathrm{kg})} \cdot 100 \%
$$

The values of the body weight were set per individual.

The Cd intake was also determined by multiplying, for each individual, the consumption of each food (average over the two $24 \mathrm{~h}$ recalls) by the median $\mathrm{Cd}$ concentration in that food item and by summing the results for all food items.

The dietary Cd intake for individuals who follow the nutritional recommendations for the consumption of vegetables or fish was similarly determined. For each individual who eats $250 \mathrm{~g}$ or more vegetables or $30 \mathrm{~g}$ or more fish per day, the consumption of a food item was multiplied with the median $\mathrm{Cd}$ concentration in the food items. The obtained results were then summed up for all food items to estimate an overall exposure.

\section{Results}

About 4,000 results of Cd analyses in food items were collected (Table 1). Cadmium was detected in $23 \%$ of the samples with a higher detection rate in matrices such as cereals, potatoes, root vegetables and offal. The highest concentrations were measured in offal (liver and kidney) of game and horse (Table 1). Although Cd has not been analyzed in cattle offal during the selected time period, it is known that the contamination level is quite high (Advice 01-2005; Vromman et al. 2008; Waegeneers 
et al. 2009). Therefore, by Royal Decree ${ }^{1}$, bovine offal of animals over 18 months slaughtered in Belgium can not be placed on the market. The $\mathrm{Cd}$ concentrations measured by Waegeneers et al. (2009) in cattle liver and kidneys of animals of $\leq 18$ months (median: $0.06 \mathrm{mg} \mathrm{kg}^{-1}$ and $0.23 \mathrm{mg} \mathrm{kg}^{-1}$, respectively; Waegeneers et al. personal communication) were lower than those measured in game and horse liver and kidneys. Cadmium is frequently found in cereal products. It was detected in all pasta samples analyzed by FASFC (Table 1). Cadmium concentrations measured by FASFC in cereals were higher than those reported by EFSA (2009). Cereals like wheat and rice can concentrate cadmium during the growth in the core of the kernel (RIVM 2003). Chaudri et al. (1995) analyzed 77 samples of wheat grain. On average, the concentration of $\mathrm{Cd}$ in bran was twice that in wholemeal flour. White flour contained about $31 \%$ less Cd than wholemeal flour. This corresponds to data of Cubadda et al. (2005), who found that milling of durum wheat, which is used for pasta-making, reduced the $\mathrm{Cd}$ content with $32 \%$. Different types of flour contain different amounts of $\mathrm{Cd}$. Cadmium concentrations in buckwheat $\left(0.046 \mathrm{mg} \mathrm{kg}^{-1}\right.$ fresh weight) were higher than in wheat flour $\left(0.025 \mathrm{mg} \mathrm{kg}^{-1}\right.$ fresh weight $)$ and than in rye flour $\left(0.017 \mathrm{mg} \mathrm{kg}^{-1}\right.$ fresh weight $)$ (Jorhem and Sundström 1993). This is reflected in the different types of bread, as measured by Tahvonen and Kumpulainen (1994) in Finnish breads: the respective Cd concentrations in rye bread, coffee bread (which is based on white wheat flour) and wholewheat bread were $0.014,0.023$ and $0.030 \mathrm{mg} \mathrm{Cd} \mathrm{kg}^{-1}$ dry weight. The types of bread that were analyzed in the current study (e.g. white, wholemeal wheat or rye bread), were not specified. Biscuits, pastries and breakfast cereals were not analyzed, neither was rice. The $\mathrm{Cd}$ concentrations in pastries and biscuits are generally slightly lower than in white bread (Bordajandi et al. 2004; Karavoltsos et al. 2002). Cadmium concentrations in different types of rice on the Swedish market ranged from $<0.001$ to $0.088 \mathrm{mg} \mathrm{kg}^{-1}$ fresh weight, with a mean of $0.024 \mathrm{mg} \mathrm{kg}^{-1}$ fresh weight (Jorhem et al. 2008).

Among vegetables, $\mathrm{Cd}$ was mainly found in spinach, celery, salsify and to a lesser extent in potatoes, leek, parsley and carrots (Table 1). According to Versluijs and Otte (2001), carrot, spinach, tomato, lettuce and celery have a high Cd uptake from soil. Van

\footnotetext{
${ }^{1}$ Royal Decree of 10 August 2005 modifying Royal Decree of 9 March 1953 concerning trade of meat slaughter and regulating the expertise of animals slaughtered in the country
} 
der Schee (cited in RIVM 2003) analyzed 500 samples of fruits, vegetables and potatoes. He found that leafy vegetables, and more specifically spinach, contained the highest Cd concentrations. The Cd concentrations in spinach reported by EFSA (2009) are comparable to those measured by the FASFC. Cadmium concentrations in fruit, dairy products, eggs, honey and meat were low (Table 1).

[Insert Table 1: Overview of Cd result in food analyzed by FASFC]

\section{Dietary Cd intake}

The dietary $\mathrm{Cd}$ intake of the Belgian adult population, calculated by a deterministic approach as the sum of the mean consumption multiplied by the median $\mathrm{Cd}$ concentration for each food item, was estimated at $0.98 \mu \mathrm{g} \mathrm{kg}^{-1}$ body weight per week (39,3\% of the TWI) (Table 2). The Cd intake was estimated at $0.77 \mu \mathrm{g} \mathrm{kg}^{-1}$ body weight per week (30.8\% of the TWI) if the lower bound scenario (ie samples with Cd levels below LOD or LOQ set to zero) was applied and at $1.18 \mu \mathrm{g} \mathrm{kg}^{-1}$ body weight per week (47.2\% of the TWI) if the upper bound scenario (ie samples with Cd levels below LOD or LOQ set to LOD or LOQ) was applied.

[Insert Table 2: Estimation of dietary Cd exposure by the Belgian adult population ( $>15$ year)]

Figure I presents the distribution of the $\mathrm{Cd}$ intake of the Belgian adult population determined with the middle bound scenario. The mean, median and $95^{\text {th }}$ percentile $\mathrm{Cd}$ intake were estimated at $0.98,0.85$ and $2.02 \mu \mathrm{g} \mathrm{kg}^{-1}$ body weight per week, respectively. Two percent of the Belgian adult population has a $\mathrm{Cd}$ intake above the TWI of $2.5 \mu \mathrm{g} \mathrm{kg}^{-1}$ body weight.

\section{[Insert Figure I]}

Additional exposure scenarios have been calculated for consumer groups who follow the nutritional recommendations for the consumption of vegetables or fish. The average 
vegetable intake by Belgian adults is only $138 \mathrm{~g}$ per day, while $350 \mathrm{~g}$ is recommended (De Vriese et al. 2006). This amount of vegetable intake is only reached by $10 \%$ of the adult population. Therefore, dietary $\mathrm{Cd}$ intake was determined for consumers who daily consume $250 \mathrm{~g}$ or more of vegetables ( $28 \%$ of the Belgian population). Mean and $95^{\text {th }}$ percentile $\mathrm{Cd}$ intake for these consumers was estimated at $1.22 \mu \mathrm{g} \mathrm{kg}^{-1}$ body weight per week (48.7\% of the TWI) and $2.25 \mu \mathrm{g} \mathrm{kg}^{-1}$ body weight per week (90\% of the TWI), respectively. The Belgian Superior Health Council recommends a mean daily fish consumption of 20-40 g by adults (HGR 2004), which corresponds to one to two portions per week. However, the average intake by the general population is only $17.9 \mathrm{~g}$ and three quarters of the populations does not meet the recommendations (De Vriese et al. 2006). Mean and $95^{\text {th }}$ percentile Cd intake for consumers who eat on average $30 \mathrm{~g}$ or more fish per day (21\% of the Belgian population), was estimated at $1.10 \mu \mathrm{g} \mathrm{kg}^{-1}$ body weight per week (43.8\% of the TWI) and $2.21 \mu \mathrm{g} \mathrm{kg}^{-1}$ body weight per week $(88.3 \%$ of the TWI), respectively.

The deterministic estimation of dietary $\mathrm{Cd}$ exposure shows that cereal products have the highest contribution to dietary $\mathrm{Cd}$ intake, followed by potatoes, pasta and vegetables (Table 3). The large contribution of cereal products and potatoes results from a high consumption of both food products combined with moderate $\mathrm{Cd}$ concentrations. Carrots and spinach have the highest contribution in the vegetable category.

[Insert table 3: Contribution of the food category to Cd intake of the Belgian adult population]

\section{Discussion}

The mean dietary $\mathrm{Cd}$ intake of the general adult population in Belgium, estimated at $0.98 \mu \mathrm{g} \mathrm{kg}^{-1}$ body weight per week is lower compared to earlier published mean intake data in Belgium and correspond with recently estimated values in neighboring countries (see below). Vromman et al. (2008) estimated the dietary Cd exposure of the Belgian 
adult population at $1.8 \mu \mathrm{g} \mathrm{kg}^{-1}$ body weight per week. This dietary exposure was based on a deterministic approach. In that study, vegetables were subdivided into three groups (leaf vegetables, tuber vegetables and root vegetables) according to the definition for establishment of maximum limits of regulation (EC) Nr 1881/2006 (Vromman et al. 2008). The Cd concentration was not measured in all food groups within the framework of that study, but partially collected from literature. Belgian dietary Cd intake was also estimated by SCOOP in 2004 at $1.9 \mu \mathrm{g} \mathrm{kg}^{-1}$ body weight per week and in 1996 at 2.74 $\mu \mathrm{g} \mathrm{kg}^{-1}$ body weight per week. This latter study included a high number of food groups. The mean exposure was calculated in a deterministic way by combination of the mean consumption with the mean concentration in different food categories (SCOOP 1996). The dietary exposure estimate in this study is close to recent estimations from most other European countries (Table 4) but is 3 times larger than the dietary exposure estimate in France, $0.319 \mu \mathrm{g} \mathrm{kg}^{-1}$ body weight per week (Leblanc et al. 2005). Cadmium concentrations measured in food by Leblanc et al. (2005) were one order of magnitude lower than those measured by FASFC or reported by other authors. The median dietary $\mathrm{Cd}$ exposure calculated by EFSA (2009) for European countries, $2.3 \mu \mathrm{g} \mathrm{kg}^{-1}$ body weight per week, was slightly lower than that reported by JECFA (2005) (2.8-4.2 $\mu \mathrm{g} \mathrm{kg}^{-}$ ${ }^{1}$ body weight per week) but higher than those reported by other authors (Table 4). Dietary Cd exposure assessment published by EFSA (2009) is based on the mean Cd concentration for each food group (with non-detected values set at half the limit of detection) and on aggregated consumption data reported in the EFSA Concise European Food Consumption database. According to EFSA (2009), the differences might indicate that a refined evaluation based on more disaggregated and representative samples, can result into lower dietary $\mathrm{Cd}$ intake estimates. Further, intake values may differ from one study to another according to the number and the nature of the food groups which are considered, the calculation methodology and the type of food consumption survey.

In the current intake calculations, $\mathrm{Cd}$ intake may be underestimated due to the absence of some food products in the dietary exposure assessment, e.g. rice, breakfast cereals, biscuits and wild mushrooms. Ingredients in mixed dishes (e.g. vegetables in soup) were not taken into account either. Rice is mainly imported from outside Europe, and therefore the mean Cd concentration derived by Jorhem et al. (2008), i.e. $0.024 \mathrm{mg} \mathrm{kg}^{-1}$, 
can be used to make an estimation of the contribution of rice to the total dietary $\mathrm{Cd}$ intake. If this value is combined with the mean rice consumption of the Belgian adult population, a weekly $\mathrm{Cd}$ intake due to the consumption of rice of $0.022 \mu \mathrm{g} \mathrm{kg}^{-1}$ body weight can be calculated, which represents $2 \%$ of the deterministically derived intake of $1.004 \mu \mathrm{g} \mathrm{kg}^{-1}$ body weight per week and which is less than $1 \%$ of the TWI.

The robustness of the high percentiles of $\mathrm{Cd}$ exposure, may be questioned because these percentiles are more sensitive to uncertainties linked to different sources (sampling size, misreporting of consumption, variability in concentrations, analytical uncertainty, ...). These percentiles are, however, important. Therefore, this methodology may be valuable for mean exposure estimations, but due to the large uncertainty for estimations realized for the highest percentiles, these percentiles should be considered with caution.

Cereal products contribute largely to the total dietary $\mathrm{Cd}$ intake, both in the current study (> 40\%) as in other studies (RIVM 2003; FSA 2009; EFSA 2009) and former Belgian estimates (SCOOP). This is mainly due to the large consumption of this food group. The consumption of wholemeal cereal products is promoted as they may provide protection against e.g. various cancers (Goodman et al. 1997; Chan et al. 2007; Suzuki et al. 2008). The mean Cd concentration found by FASFC in bread $\left(0.019 \mathrm{mg} \mathrm{kg}^{-1}\right)$ is comparable to those found in white bread in other studies (range $0.015-0.023 \mathrm{mg} \mathrm{kg}^{-1}$; Bordajandi et al. 2004; Karavoltsos et al. 2002; Marti-Cid et al 2008; Tahvonen and Kumpulainen 1994). As wholemeal flour contains about $30 \%$ more Cd than white flour (Chaudri et al. 1995), consumption of wholemeal bread might increase the Cd intake up to $6.6 \%$ (from 0.98 to $1.05 \mu \mathrm{g} \mathrm{kg}^{-1}$ body weight per week). This increase will, on the other hand, be compensated to a large extent by the lower fractional absorption of $\mathrm{Cd}$ in the gastrointestinal tract, due to the presence of phytates, nutrients and fibers in the whole grain and bran fractions (Moberg et al. 1987; Berglund et al 1994; Lind et al. 1998; Reeves and Chaney 2002; Andersen et al. 2004). Therefore, the higher Cd content does not seem to be a reason to decrease the consumption of wholemeal wheat. 


\section{Conclusion}

The mean, median and $95^{\text {th }}$ percentile dietary exposure to $\mathrm{Cd}$ of the Belgian adult population were estimated at $0.98,0.85$ and $2.02 \mu \mathrm{g} \mathrm{kg}^{-1}$ body weight per week. Cadmium intake was estimated to be lower than the TWI of $2.5 \mu \mathrm{g} \mathrm{kg}^{-1}$ body weight for $98 \%$ of the Belgian adult population. Dietary exposure to $\mathrm{Cd}$ for specific consumer groups such as consumers who follow the nutritional recommendations for the consumption of vegetables and fish, is higher than for the general adult population.

Dietary Cd exposure of the Belgian adult population was comparable to that in several other European countries. Cereal products and potatoes are the main food groups that contribute to $\mathrm{Cd}$ exposure in Belgium.

\section{Acknowledgement}

The authors wish to thank the Belgian Federal Agency for the Safety of the Food Chain for providing the data used in this study.

\section{References}

Advice 01-2005 of the Scientific Committee of the FASFC. Contamination de la chaîne alimentaire par des métaux lourds à proximité des sites d'implantation d'Umicore [Internet]. Brussels (Belgium): Belgian Federal Agency for the Safety of the Food Chain [cited 2005 januari 24]. Available from http://www.favvafsca.fgov.be/home/com-sci/doc/avis05/Avis_2005-01.pdf

Åkesson A, Julin B, Wolk A. 2008. Long-term dietary cadmium intake and postmenopausal endometrial cancer incidence: a population-based prospective cohort study. Cancer Res. 68 (15): 6435-41.

Andersen O, Nielsen J, Nordberg GF. 2004. Nutritional interactions in intestinal cadmium uptake - Possibilities for risk reduction. BioMetals. 17: 543-547. 
Berglund M, Åkesson A, Nermell B,Vahter M. 1994. Intestinal absorption of dietary cadmium in women depends on body iron stores and fiber intake. Environ Health Perspect.102: 1058-1066.

BfR (Bundesinstitut für Riskobewertung), 2009. Cadmium : New challenge for food safety? BfR status seminar on cadmium in the food chain[Internet]: Bundesinstitut für Riskobewertung; [cited 2009 July 15]. Available from http://www.bfr.bund.de/cd/30246.

Bocio A, Nadal M, Domingo JL. 2005. Human exposure to metals through the diet in Tarragona, Spain. Biol Trace Elem Res. 104: 193-201.

Bordajandi LR, Gómez G, Abad E, Rivera J, Fernández-Bastón M, Blasco J, González MJ. 2004. Survey of persistent organochlorine contaminants (PCBs, PCDD/Fs, and PAHs), heavy metals ( $\mathrm{Cu}, \mathrm{Cd}, \mathrm{Zn}, \mathrm{Pb}$, and $\mathrm{Hg}$ ), and arsenic in food samples from Huelva (Spain): levels and health implications. J. Agric. Food Chem. 52: 992-1001.

Chan JM, Wang F, Holly EA. 2007. Whole grains and risk of pancreatic cancer in a large population-based case-control study in the San Francisco Bay area, California. Am J Epidemiol. 166: 1174-1185.

Chaudri AM, Zhao FJ, McGrath SP, Crosland AR. 1995. The Cadmium Content of British Wheat Grain. J. Environ. Qual. 24: 850-855.

Cubadda F, Raggi A, Marconi E. 2005. Effects of processing on five selected metals in the durum wheat food chain. Microchem J. 79: 97-102.

De Vriese S, Debacker G, de Henauw S, Huybrechts I, Kornitzer M, Leveque A, Moreau M, Van Oyen H. 2005. The Belgian food consumption survey: aims, design and methods. Arch Public Health 63: 1-16.

De Vriese S, Huybrechts I, Moreau M, Van Oyen H. 2006. Enquête de consommation alimentaire Belge 1 - 2004 Service d'Epidémiologie, 2006; Bruxelles Institut Scientifique de Santé Publique Nº de Dépôt : D/2006/2505/16, IPH/EPI REPORTS $\mathrm{N}^{\circ} 2006-014$.

EC (European Communities), 2007. European Risk Assessment Report. Cadmium metal. Part II. Human Health. EUR 22767 EN. Office for Official Publications of the European Communities, Luxembourg. 
EFSA, 2009. Scientific Opinion of the Panel on Contaminants in the Food Chain on a request from the European Commission on cadmium in food. The EFSA J. 980: 1139.

FAO/WHO (Food and Agriculture organization/ World Health Organization), 2000. Evaluation of certain food additives (Fifty-fifth report of the Joint FAO/WHO Expert Committee on Food Additives). WHO Food Additives Series 46.

FAO/WHO (Food and Agriculture organization/ World Health Organization), 2004. Evaluation of certain food additives (Sixty-first report of the Joint FAO/WHO Expert Committee on Food Additives). WHO Food Additives Series 52.

Fouassin A, Fondu M. 1981. Evolutie van het gemiddelde lood-en cadmiumgehalte in de dagelijkse voeding in België. Belgisch Archief van Sociale Geneeskunde, Hygiëne, Arbeidsgeneeskunde en Gerechtelijke Geneeskunde, 39, 1-14.

FSA (Food Standards Agency), 2009. Measurement of the concentrations of metals and other elements from the 2006 UK total diet study. Food Survey Information Sheet 01/09. 45 pp.

Goodman MT, Wilkens LR, Hankin JH, Lyu C, Wu AH, Kolonel LN. 1997. Association of soy and fiber consumption with the risk of endometrial cancer. Am J Epidemiol. 146: 294-306.

HGR (Hoge Gezondheidsraad), 2004. Vis en Gezondheid bij Volwassenen FOD Volksgezondheid, Veiligheid van de Voedselketen en Leefmilieu. Superior Health Council. Wettelijk depotnr. D/2004/7795/3. ISBN nr. 9076994315. https://portal.health.fgov.be/pls/portal/docs/PAGE/INTERNET_PG/HOMEPAGE_ MENU/ABOUTUS1_MENU/INSTITUTIONSAPPARENTEES1_MENU/HOGE GEZONDHEIDSRAAD1_MENU/ADVIEZENENAANBEVELINGEN1_MENU/ ADVIEZENENAANBEVELINGEN1_DOCS/7617_VIS\%20EN\%20GEZONDHE ID_NL_2004.PDF

JECFA (Joint FAO/WHO Expert Committee on Food Additives), 2005. Summary and conclusions of the sixty-four meeting of the Joint FAO/WHO Expert Committee on Food Additives (JECFA). 
Jorhem L, Sundström B. 1993. Levels of lead, cadmium, zinc, copper, nickel, chromium, manganese, and cobalt in foods on the Swedish market, 1983-1990. J. Food Compos. Anal. 6: 223-241.

Jorhem L, Åstrand C, Sundström B, Baxter M, Stokes P, Lewis J, Petersson Grawé K. 2008. Elements in rice from the Swedish market: 1. Cadmium, lead and arsenic (total and inorganic). Food Addit Contam. 25: 284-292.

Karavoltsos S, Sakellari A, Dimopoulos M, Dasenakis M, Scoullos M. 2002. Cadmium content in foodstuffs from the Greek market. Food Addit Contam. 19: 954-962.

Kobayashi E, Suwazono Y, Dochi M, Honda R, Kido T. 2009. Influence of consumption of cadmium-polluted rice or Jinzu river water on occurrence of renal tubular dysfunction and/or Itai Itai disease. Biol Trace Elem Res. 127: 257-268.

Larsen EH, Andersen NL, Møller A, Petersen A, Mortensen GK, Petersen J. 2002. Monitoring the content and intake of trace elements from food in Denmark. Food Addit Contam. 19: 33-46.

Lauwerys R, Bernard A, Buchet J-P, Roels H, Bruaux P, Claeys F, Ducoffre G, De Plaen P, Staessen J, Amery A, et al. 1991. Does environmental exposure to cadmium represent a health risk? Conclusions from the Cadmibel study. Acta. Clin. Belg. 46: 219-225.

Lauwerys RR, Bernard AM, Roels HA. Buchet J-P. 1994. Cadmium: exposure markers as predictors of nephrotoxic effects. Clin. Chem. 40: 1391-1394.

Leblanc J-C, Guérin T, Noël L, Calamassi-Tran G, Volatier J-C, Verger P. 2005. Dietary exposure estimates of 18 elements from the $1^{\text {st }}$ French total diet study. Food Addit Contam. 22: 624-641.

Lind Y, Engman J, Jorhem L, Glynn AW. 1998. Accumulation of cadmium from wheat bran, sugar-beet fibre, carrots and cadmium chloride in the liver and kidneys of mice. Br J Nutr. 80: 205-211.

Llobet JM, Falcó G, Casas C, Teixidó A, Domingo JL. 2003. Concentrations of arsenic, cadmium, mercury, and lead in common foods and estimated daily intake by children, adolescents, adults, and seniors of Catalonia, Spain. J Agric Food Chem. 51: $838-842$. 
Martí-Cid R, Llobet JM, Castell V, Domingo JL. 2008. Dietary intake of arsenic, cadmium, mercury, and lead by the population of Catalonia, Spain. Biol Trace Elem Res. 125: 120-132.

Marzec Z, Schlegel-Zawadzka M. 2004. Exposure to cadmium, lead and mercury in the adult population from Eastern Poland, 1990-2002. Food Addit Contam. 21 (10): 963-970.

Maudoux JP, Saegerman C, Rettigner C, Houins G, Van Huffel X, Berkvens D. 2006. Food safety surveillance through a risk based control programme: Approach employed by the Belgian Federal Agency for the Safety of the Food Chain. Vet Quarterly. 28:140-154.

Moberg A, Hallmans G, Sjöström R, Wing KR. 1987. The effect of wheat bran on the absorption and accumulation of cadmium in rats. Br J Nutr. 58: 383-391.

Nawrot T, Plusquin M, Hogervost J, Roels HA, Celis H, Thijs, Vangronsveld J, Van Hecke E, Staessen JA. 2006. Environmental exposure to cadmium and risk of cancer: a prospective population-based study. Lancet Oncol. 7(2):119-126.

Reeves PG, Chaney RL. 2002. Nutritional status affects the absorption and whole-body and organ retention of cadmium in rats fed rice-based diets. Environ Sci Technol. 36: 2684-2692.

RIVM (National Institute of Public Health and the Environment), 2003. de WinterSorkina R, Bakker MI, van Donkersgoed G, van Klaveren JD. Dietary intake of heavy metals (cadmium, lead and mercury) by the Dutch population. RIVM report 320103001.

Rubio C, Hardisson A, Reguera JI, Revert C, Lafuente MA, Gonzalez-Iglesias T. 2006. Cadmium dietary intake in the Canary Islands, Spain. Environ. Res. 100 (1): 123129.

SCF (Scientific Committee for Food), 1995. Opinon on cadmium. http://ec.europa.eu/food/fs/sc/scf/reports/scf_reports_36.pdf

SCOOP. 1996. Reports on tasks for scientific cooperation. Task 3.2.4. Dietary exposure to cadmium. European Commission, Directorate-General for industry. 
SCOOP. 2004. Reports on tasks for scientific cooperation. Task 3.2.11. Assessment of the dietary exposure to arsenic, cadmium, lead and mercury of the population of the EU Member states. European Commission, Directorate-General Health and Consumer Protection, March 2004.

Suzuki R, Rylander-Rudqvist T, Ye W, Saji S, Adlercreutz H, Wolk A. 2008. Dietary fiber intake and risk of postmenopausal breast cancer defined by estrogen and progesterone receptor status-A prospective cohort study among Swedish women. Int J Cancer. 122: 403-412.

Tahvonen R, Kumpulainen J. 1994. Lead and cadmium in Finnish breads. Food Addit Contam. 11: 621-631.

Versluijs CW, Otte PF. 2001. Accumulatie van metalen in planten. RIVM report 711701024 (in Dutch).

Vose D. 2006. Risk analysis - a quantitative guide. 2nd ed. Chichester (UK): Wiley.

Van Assche F, Ciarletta P. 1993. Environmental exposure to cadmium in Belgium: decreasing trends during the 1980s. In: Heavy Metals in the Environment, Proceedings of the 9th International Conference, Volume I (R. J., Allen and J. O., Nriagu, Eds.) 34-37.

Vromman V, Saegerman C, Pussemier L, Huyghebaert A, De Temmerman L, Pizzolon JC, Waegeneers N. 2008. Cadmium in the food chain near non-ferrous metal production sites. Food Addit Contam. 25 (3): 293-301.

Waegeneers N, Pizzolon J-C, Hoenig M, De Temmerman L. 2009. The European maximum level for cadmium in bovine kidneys is in Belgium only realistic for cattle up to 2 years of age. Food Addit Contam. 26 (9): 1239-1248.

World Health Organization (WHO), 1992. Environmental Health Criteria 134 Cadmium International Programme on Chemical Safety (IPCS) Monograph.

WHO (World Health Organization), 1995. GEMS/Food - EURO Second workshop on reliable evaluation of low-level contamination of food. Kulmbach, Federal Republic of Germany, 26-27 May 1995. 


\begin{tabular}{|c|c|c|c|c|c|c|c|}
\hline Food & $\begin{array}{l}\text { Number } \\
\text { sample }\end{array}$ & $\begin{array}{c}\mathrm{Nb} \\
<\mathrm{LOQ}\end{array}$ & $\begin{array}{c}\text { Percent } \\
\text { of } \\
\text { sample } \\
<L O Q\end{array}$ & $\underset{\left(\mathrm{mg} \mathrm{kg}^{-1}\right)}{\operatorname{Min}}$ & $\begin{array}{c}\operatorname{Max} \\
\left(\mathrm{mg} \mathrm{kg}^{-1}\right)\end{array}$ & $\begin{array}{c}\text { Mean } \\
\left(\mathrm{mg} \mathrm{kg}^{-1}\right)\end{array}$ & $\begin{array}{c}\mathrm{P} 50 \\
\left(\mathrm{mg} \mathrm{kg}^{-1}\right)\end{array}$ \\
\hline Bread & 40 & 1 & 3 & 0.005 & 0.051 & 0.019 & 0.019 \\
\hline Pasta, noodle & 38 & 0 & 0 & 0.011 & 0.130 & 0.060 & 0.054 \\
\hline Cereals (wheat) & 10 & 0 & 0 & 0.025 & 0.099 & 0.051 & 0.052 \\
\hline Potatoes & 88 & 21 & 24 & 0.005 & 0.140 & 0.023 & 0.021 \\
\hline Garlic & 7 & 3 & 43 & 0.005 & 0.048 & 0.014 & 0.011 \\
\hline Courgette & 7 & 5 & 71 & 0.005 & 0.047 & 0.012 & 0.005 \\
\hline Tomato & 10 & 7 & 70 & 0.005 & 0.021 & 0.008 & 0.005 \\
\hline Pea & 15 & 15 & 100 & 0.050 & 0.050 & 0.050 & 0.050 \\
\hline Onion & 33 & 18 & 55 & 0.005 & 0.059 & 0.014 & 0.005 \\
\hline Carrot & 96 & 13 & 14 & 0.005 & 0.084 & 0.025 & 0.021 \\
\hline Radish & 5 & 4 & 80 & 0.005 & 0.014 & 0.007 & 0.005 \\
\hline Salsify & 34 & 0 & 0 & 0.014 & 0.081 & 0.045 & 0.042 \\
\hline Leek & 30 & 10 & 33 & 0.005 & 0.15 & 0.030 & 0.0185 \\
\hline Celery & 29 & 3 & 10 & 0.005 & 0.240 & 0.044 & 0.027 \\
\hline Celeriac & 18 & 3 & 17 & 0.005 & 0.180 & 0.068 & 0.059 \\
\hline $\begin{array}{l}\text { Lettuce (lettuce, lamb's } \\
\text { lettuce rocket,...) }\end{array}$ & 59 & 24 & 41 & 0.005 & 0.087 & 0.022 & 0.011 \\
\hline Spinach & 50 & 0 & 0 & 0.017 & 0.290 & 0.079 & 0.066 \\
\hline Fennel & 10 & 8 & 80 & 0.005 & 0.026 & 0.008 & 0.005 \\
\hline Parsley & 16 & 3 & 19 & 0.005 & 0.110 & 0.032 & 0.024 \\
\hline Endive & 6 & 4 & 67 & 0.005 & 0.023 & 0.009 & 0.005 \\
\hline $\begin{array}{l}\text { Cabbage (white cabbage, } \\
\text { cauliflower,...) }\end{array}$ & 56 & 52 & 93 & 0.002 & 0.005 & 0.005 & 0.005 \\
\hline Cultivated mushroom & 55 & 39 & 71 & 0.005 & 3.000 & 0.098 & 0.005 \\
\hline Gooseberry & 9 & 9 & 100 & 0.005 & 0.005 & 0.005 & 0.005 \\
\hline Strawberry & 11 & 11 & 100 & 0.005 & 0.005 & 0.005 & 0.005 \\
\hline Grape & 6 & 6 & 100 & 0.005 & 0.005 & 0.005 & 0.005 \\
\hline Dried fruit - pine nuts & 5 & 0 & 0 & 0.106 & 0.153 & 0.128 & 0.124 \\
\hline Melon & 9 & 8 & 89 & 0.005 & 0.012 & 0.006 & 0.005 \\
\hline Honey & 141 & 130 & 92 & 0.001 & 0.079 & 0.004 & 0.0025 \\
\hline Milk & 179 & 171 & 96 & 0.00025 & 0.007 & 0.001 & 0.0005 \\
\hline Cheese & 25 & 21 & 84 & 0.0005 & 0.009 & 0.002 & 0.001 \\
\hline Yoghurt & 20 & 19 & 95 & 0 & 0.003 & 0.001 & 0.001 \\
\hline Eggs & 137 & 135 & 99 & 0.00005 & 0.0131 & 0.001 & 0.0005 \\
\hline Fish & 952 & 895 & 94 & 0.001 & 1.5 & 0.031 & 0.025 \\
\hline Molluscs & 46 & 4 & 9 & 0.005 & 0.88 & 0.212 & 0.18 \\
\hline Crustaceans & 157 & 113 & 72 & 0.005 & 0.37 & 0.039 & 0.025 \\
\hline Duck meat & 18 & 18 & 100 & 0.005 & 0.005 & 0.005 & 0.005 \\
\hline Rabbit meat & 35 & 34 & 97 & 0.001 & 0.029 & 0.005 & 0.005 \\
\hline Chicken meat & 121 & 120 & 99 & 0.005 & 0.2 & 0.007 & 0.005 \\
\hline Turkey meat & 30 & 30 & 100 & 0.005 & 0.005 & 0.005 & 0.005 \\
\hline Snail & 8 & 8 & 0 & 0.031 & 0.3 & 0.129 & 0.094 \\
\hline Sheep \& lamb meat & 41 & 41 & 100 & 0.001 & 0.005 & 0.005 & 0.005 \\
\hline Pork meat & 225 & 225 & 100 & 0.001 & 0.01 & 0.005 & 0.005 \\
\hline Bovine meat & 268 & 267 & 99.6 & 0.005 & 0.043 & 0.005 & 0.005 \\
\hline Veal meat & 34 & 34 & 100 & 0.005 & 0.005 & 0.005 & 0.005 \\
\hline Bovine liver ${ }^{*}$ & 11 & 0 & 0 & 0.04 & 0.143 & 0.072 & 0.059 \\
\hline Bovine kidney* & 11 & 0 & 0 & 0.093 & 0.635 & 0.012 & 0.23 \\
\hline Horse meat & 70 & 8 & 11 & 0.005 & 0.36 & 0.042 & 0.031 \\
\hline Horse liver & 20 & 0 & 0 & 0.028 & 72.6 & 5.315 & 1.64 \\
\hline Horse kidney & 15 & 0 & 0 & 4.430 & 71.7 & 19.463 & 14.7 \\
\hline
\end{tabular}

Table 1: Overview of various food items in which Cd was measured by FASFC in 2006, 2007 and 2008 (Number of samples analyzed, number of samples $<$ quantification limit (LOQ), percent of samples $<\mathrm{LOQ}$, minimum, maximum, mean and median (P50) Cd concentration. The concentrations are expressed on a fresh weight basis.

*Vromman Valérie. Email : valerie.vromman@afsca.be 


\begin{tabular}{|l|c|c|c|c|c|c|c|} 
Game meat & 268 & 245 & 91 & 0.005 & 0.029 & 0.006 & 0.005 \\
\hline Game liver & 46 & 0 & 0 & 0.015 & 52.27 & 2.341 & 0.17 \\
\hline Game kidney & 37 & 0 & 0 & 0.2 & 14.47 & 2.768 & 1.63 \\
\hline Fruit juice & 56 & 54 & 96 & 0.005 & 0.016 & 0.005 & 0.005 \\
\hline $\begin{array}{l}\text { Mineral water (FAL“, 2000- } \\
\text { 2003) }\end{array}$ & 14 & 0 & 0 & 0.00005 & 0.0003 & 0.0002 & 0.0002 \\
\hline Chocolate & 10 & 5 & 50 & 0.010 & 0.090 & 0.034 & 0.025 \\
\hline
\end{tabular}

*Waegeneers et al. personal communication; "Institute of Plant Nutrition and Soil Science, Federal Agricultural Research Center (FAL) Braunschweig (2000-2003) 
Table 2: Estimation of Cd dietary exposure by the Belgian adult population ( $>15$ year)

\begin{tabular}{|c|c|c|c|}
\hline Food & $\begin{array}{c}\text { Mean } \\
\text { consumption } \\
\text { (kg kg }^{-1} \text { body } \\
\text { weight per day) }\end{array}$ & $\begin{array}{c}\text { Exposure }^{*} \\
\left(\mu \mathrm{kg}^{-1} \text { body }\right. \\
\text { weight per week })\end{array}$ & $\begin{array}{c}\% \text { TWI } \\
\left(=2,5 \mu g \mathrm{~kg}^{-1}\right. \\
\text { body weight per } \\
\text { week) }\end{array}$ \\
\hline Bread & $1.75 \mathrm{E}-03$ & 0.233 & 9.31 \\
\hline Pasta, noodle & 4.66E-04 & 0.176 & 7.05 \\
\hline Cereals (wheat) & $3.70 \mathrm{E}-06$ & 0.001 & 0.05 \\
\hline Potatoes & 1.57E-03 & 0.226 & 9.03 \\
\hline Garlic & $2.58 \mathrm{E}-06$ & 0.0002 & 0.01 \\
\hline Courgette & $2.52 E-05$ & 0.001 & 0.04 \\
\hline Tomato & $4.55 E-04$ & 0.016 & 0.64 \\
\hline Pea & 3.37E-05 & 0.012 & 0.47 \\
\hline 28 & $9.24 \mathrm{E}-05$ & 0.003 & 0.13 \\
\hline Carrot & $1.66 \mathrm{E}-04$ & 0.024 & 0.97 \\
\hline Radish & 2.46E-06 & 0.0001 & 0.00 \\
\hline Salsify & $5.95 E-06$ & 0.002 & 0.07 \\
\hline Leek & $5.28 \mathrm{E}-05$ & 0.007 & 0.27 \\
\hline Celery & 1.33E-05 & 0.003 & 0.10 \\
\hline Celeriac & $1.08 \mathrm{E}-05$ & 0.004 & 0,18 \\
\hline Lettuce (lettuce, lamb's lettuce, rocket,...) & $9.76 \mathrm{E}-05$ & 0.008 & 0.30 \\
\hline Spinach & 4.89E-05 & 0.022 & 0.90 \\
\hline Fennel & 3.96E-06 & 0,0001 & 0.01 \\
\hline Parsley & $6.81 \mathrm{E}-07$ & 0.0001 & 0,00 \\
\hline Endive & 1.48E-05 & 0.001 & 0.02 \\
\hline Cabbage (white cabbage, cauliflower,...) & 2.07E-04 & 0.007 & 0.29 \\
\hline Cultivated mushroom & 4.23E-05 & 0.001 & 0.06 \\
\hline Gooseberry & 3.89E-06 & 0.0001 & 0.01 \\
\hline Strawberry & 7.64E-05 & 0.003 & 0.11 \\
\hline Grape & 8.05E-05 & 0.003 & 0.11 \\
\hline Dried fruit - pine nuts & 3.33E-07 & 0.0003 & 0.01 \\
\hline Melon & $6.11 \mathrm{E}-05$ & 0.002 & 0.09 \\
\hline Honey & $1.61 \mathrm{E}-05$ & 0.0003 & 0.01 \\
\hline Milk & $1.40 \mathrm{E}-03$ & 0.005 & 0.20 \\
\hline Cheese & $1.48 \mathrm{E}-04$ & 0.001 & 0.04 \\
\hline Yoghurt & $5.15 \mathrm{E}-04$ & 0.004 & 0.14 \\
\hline Eggs & $1.44 \mathrm{E}-04$ & 0.001 & 0.02 \\
\hline Fish & $2.51 \mathrm{E}-04$ & 0.044 & 1.76 \\
\hline Molluscs & $2.56 \mathrm{E}-05$ & 0.032 & 1.29 \\
\hline Crustaceans & 4.05E-05 & 0.007 & 0.28 \\
\hline Duck meat & 4.89E-06 & 0.0002 & 0.01 \\
\hline Rabbit meat & $1.85 \mathrm{E}-05$ & 0.001 & 0.03 \\
\hline Chicken meat & 2.48E-04 & 0.009 & 0.35 \\
\hline Turkey meat & $5.48 \mathrm{E}-05$ & 0.002 & 0.08 \\
\hline Snail & $9.18 \mathrm{E}-07$ & 0.001 & 0.02 \\
\hline Sheep \& lamb meat & 3.35E-04 & 0,012 & 0.47 \\
\hline Pork meat & $1.99 \mathrm{E}-04$ & 0.007 & 0.28 \\
\hline Bovine meat & $2.54 \mathrm{E}-04$ & 0.009 & 0.36 \\
\hline
\end{tabular}




\begin{tabular}{|l|c|c|c|} 
Veal meat & $5.22 \mathrm{E}-05$ & 0.002 & 0.07 \\
\hline Horse meat & $1.31 \mathrm{E}-05$ & 0.003 & 0.11 \\
\hline Game meat & $1.73 \mathrm{E}-05$ & 0.001 & 0.02 \\
\hline Liver (horse, game, bovine) & $1.75 \mathrm{E}-06$ & 0.003 & 0.11 \\
\hline Kidneys (horse, game, bovine) & $2.43 \mathrm{E}-07$ & 0.003 & 0.12 \\
\hline Fruit juice & $9.96 \mathrm{E}-04$ & 0.035 & 1.39 \\
\hline Mineral water (FAL 2000-2003) & $8.80 \mathrm{E}-03$ & 0.012 & 0.49 \\
\hline Chocolate & $2.01 \mathrm{E}-04$ & 0.035 & 1.41 \\
\hline Sum & & $\mathbf{0 . 9 8}$ & $\mathbf{3 9 . 3}$ \\
\hline
\end{tabular}


Table 3 : Contribution of food categories to the dietary exposure of the Belgian adult population

\begin{tabular}{|c|c|}
\hline Categories of food & $\begin{array}{c}\text { Contribution } \\
\text { to exposure } \\
(\%)\end{array}$ \\
\hline Cereals (wheat), bread & 23.83 \\
\hline Potatoes & 22.99 \\
\hline Pasta, noodle & 17.94 \\
\hline Vegetables & 11.34 \\
\hline Beverages (water, juice) & 4.80 \\
\hline Meat (poultry, bovine, pork, horse, game) & 4.57 \\
\hline Fish & 4.47 \\
\hline Crustaceans, bivalves & 4.01 \\
\hline Chocolate & 3.58 \\
\hline Dairy products & 0.97 \\
\hline Fruit & 0.82 \\
\hline Offal (horse, game, bovine) & 0.57 \\
\hline Eggs & 0.05 \\
\hline Honey & 0.03 \\
\hline
\end{tabular}


Table 4. Comparison of dietary Cd intake in different European countries.

\begin{tabular}{|l|c|l|}
\hline \multicolumn{1}{|c|}{ Country } & $\begin{array}{c}\text { Cd intake } \\
\left(\boldsymbol{\mu g} \mathbf{~ k g}^{-1} \text { body weight per }\right. \\
\text { week) }\end{array}$ & \multicolumn{1}{|c|}{ Reference } \\
\hline Belgium & 0.98 & This study \\
\hline The Netherlands & $\begin{array}{c}1.26 \text { (short-term intake) } \\
0.98 \text { (long-term intake) }\end{array}$ & RIVM 2003 \\
\hline United Kingdom & $0.98-1.19$ & FSA 2009 \\
\hline Germany & 1.45 & BfR 2009 \\
\hline Denmark & 1.87 & Larsen et al. 2002 \\
\hline Sweden & 1.75 & Akesson et al. 2008 \\
\hline Spain (Tarragona) & 1.67 & Bocio et al. 2005 \\
\hline Spain (Catalonia) & 0.77 & Llobet et al. 2003 \\
\hline Spain (Huelva) & 1.1 & Bordajandi et al. 2004 \\
\hline Spain (Canary Islands) & 0.319 & Rubio et al. 2006 \\
\hline France & $1.9-3.0$ & Leblanc et al. 2005 \\
\hline Europe & 2.33 & EFSA 2009 \\
Belgium & & \\
\hline
\end{tabular}




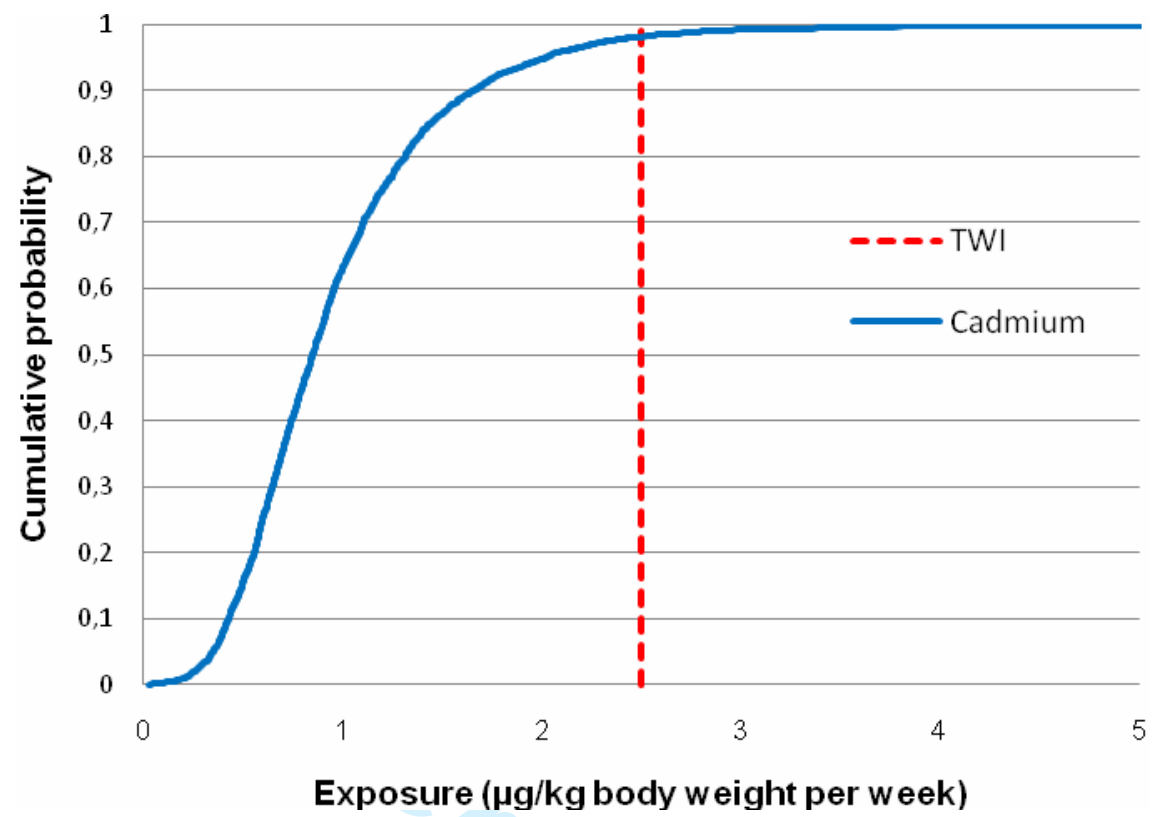

Figure 1: Distribution of dietary Cd Intake for the Belgian adult population. The TWI value established by EFSA is shown as the vertical line.

*Vromman Valérie. Email : valerie.vromman@afsca.be 